\title{
Million Colony Forming Units per Milliliter
}

National Cancer Institute

\section{Source}

National Cancer Institute. Million Colony Forming Units per Milliliter. NCI Thesaurus. Code C68904.

A derived unit of viable cell concentration defined as the number of million colony forming units (10E6 CFU) in one milliliter of substance. 